\title{
Efektivitas Kepemimpinan Wanita Dalam Mengatasi Konflik Sosial (Studi Pada Kepemimpinan Bupati Kabupaten Bima Dalam Satu Periode)
}

\author{
Mardiah$^{1}$, Abdul Kharis ${ }^{2}$, Lies Sholihah ${ }^{3}$ \\ 1Prodi Administrasi Publik, Universitas Muhammadiyah Mataram , Indonesia \\ 2Prodi Administrasi Bisnis, Universitas Muhammadiyah Mataram, Indonesia \\ 3Prodi Administrasi Publik, Universitas Muhammadiyah Mataram, Indonesia
}

INFO ARTIKEL

Riwayat Artikel:

Diterima: 14-02-2018

Disetujui: 02-03-2018

\section{Kata Kunci:}

1. Efektivitas

2. Kepemimpinan

3. Wanita

4. Konflik

5. Sosial

Keywords:

1. Effectiveness

2. Women's

3. Leadership

4. Social

5. Conflict

\section{ABSTRAK}

Abstrak: Provinsi Nusa Tenggara Barat ada satu daerah yang dipimpin oleh pemimpin wanita, yaitu kabupaten Bima yang dikenal dengan stigma "Zona Merah" daerah rawan konflik. Indah Damayanti Putri atau yang akrab disapa Dae Dinda menjadi wanita pertama di Bima yang menjabat Bupati. Konflik sosial yang menjadi permasalahan pelik di Kabupaten Bima merupakan tantangan tersendiri bagi seorang pemimpin dalam mencari solusinya.

Tujuan penelitian ini untuk mengetahui efektivitas kepemimpinan bupati Kabupaten Bima dalam menangani konflik sosial. Metode yang digunakan dalam penelitian ini adalah metode kualitatif dengan pendekatan deskriptif.

Hasil penelitian ini menunjukan bahwa kepemimpinan bupati kabupaten Bima dinilai sudah sangat efektif, hal tersebut diukur dari beberapa indikator, yaitu sifat/kepribadian pemimpin, motivasi kepemimpinan serta komptensi/kemampuan dalam memimpin. Keberhasilan tersebut dibuktikan dengan berkurangnya jumlah terjadi konflik dan kualitas konflik yang melemah yaitu konflik yang terjadi karena perkelahian remaja bukan lagi konflik antar kelompok yang besar seperti konflik antar kampung.

West Nusa Tenggara Province is an area headed by female leaders, namely Bima district known as the "Red Zone" of conflict prone areas. Indah Damayanti Putri or who is familiarly called Dae Dinda became the first woman in Bima who served Regent. Social conflicts that become a complicated problem in Kabupaten Bima is a challenge for a leader in finding a solution.

The purpose of this research is to know the effectiveness of Bima regent leadership in handling social conflict. The method used in this research is qualitative method with descriptive approach.

The results of this study indicate that the leadership of Bima district regency is considered very effective, it is measured from several indicators, namely the character / personality of leaders, leadership motivation and competence / ability in the lead. The success is evidenced by the decrease in the number of conflicts and the quality of the weakened conflict that is the conflict caused by teenagers fight is no longer a large conflict between groups such as conflict between villages. 


\section{Latar Belakang}

Organisasi tidak dapat tumbuh dan berkembang tanpa adanya keberhasilan dari unsur manusia dengan kemampuan manajerial dan moralitas kerja yang memadai. Manusia selalu berperan aktif dan berada pada posisi dominan dalam setiap kegiatan organisasi, karena manusia merupakan perencana, pelaku dan penentu terwujudnya tujuan organisasi. Maka dari itu kemampuan seorang pemimpin sangat berpengaruh dalam kemajuan suatu organisasi.

Kepemimpinan dipandang sangat penting karena dua hal: pertama, adanya kenyataan bahwa penggantian pemimpin seringkali mengubah kinerja suatu unit, instansi atau organisasi; kedua, hasil penelitian yang menunjukkan bahwa salah satu faktor internal yang memengaruhi keberhasilan organisasi adalah kepemimpinan, mencakup proses kepemimpinan pada setiap jenjang organisasi, kompetensi dan tindakan pemimpin yang bersangkutan. Kenyataan dan/atau gagasan, serta hasil penelitian tersebut tak dapat dibantah kebenarannya. Semua pihak maklum adanya, sehingga muncul jargon "ganti pimpinan, ganti kebijakan", bahkan sampai hal-hal teknis seperti ganti tata ruang kantor, ganti kursi, atau ganti warna dinding.

Pemimpin mempunyai tugas penting dalam menjalankan roda pemerintahan, yang sangat di harapkan menggunakan kepemimpinan yang efektif dalam melaksanakan tanggung jawab dan kewajiban yang akan dihadapi sebagai aparatur Negara dalam menjalankan pelayanan publik, sehingga sangat diharapkan adanya komitmen serta kelebihan-kelebihan khusus dalam menggerakkan potensi sumber daya manusia yang di pimpin.

Salah satu isu yang menarik dalam kepemimpinan adalah pengaruh gender dalam kepemimpinan. Dalam sudut pandang gender, terdapat stigma bahwa laki-laki dianggap lebih unggul daripada perempuan. Stigma tersebut menempatkan perempuan sebagai warga masyarakat kelas dua, termasuk dalam hal kepemimpinan. Dikarenakan stigma tesebut, kemudian muncul pandangan bahwa kekuasaan dan kepemimpinan merupakan domain laki-laki yang terwujud dalam identitas maskulin. Sebagai akibatnya, berkembanglah resistensi terhadap kepemimpinan perempuan. Hingga saat ini, masyarakat masih cenderung bersikap skeptis terhadap pemimpin perempuan. Hal tersebut tercermin dalam jumlah pemimpin perempuan yang masih jauh dibawah pemimpin laki-laki.

Isu gender akhir-akhir ini semakin ramai dibicarakan, gender sendiri berasal dari bahasa Inggris yang berarti "jenis kelamin" dimana diartikan sebagai perbedaan yang tampak antara laki-laki dan perempuan dilihat dari segi nilai dan tingkah laku. Secara biologis perempuan berbeda dengan laki-laki, tetapi dari segi hak dan kewajiban sebagai manusia adalah sama. Keberadaan perempuan bukan sekedar pelengkap bagi laki-laki,melainkan mitra sejajar dalam berbagai aspek kehidupan, baik yang bersifat domestik seperti rumah tangga maupun publik. Suatu hal yang tidak dapat dipungkiri adalah perempuan merupakan bagian integral dari masyarakat namun demikian, kenyataan yangterjadi di masyarakat seringkali tidak sesuai dengan pernyataan tersebut, dimana masih terjadi diskriminasi dan ketidakadilan terhadap perempuan. Hal ini sesuai dengan hasil penelitian para ahli yang menelusuri kemajuan kaum perempuan melalui lembagalembaga Skandinavia yang telah mencermati keterwakilan perempuan. Penelitian tersebut menunjukkan bahwa, sementara kaum perempuan tetap kelompok minoritas,terdapat dua bentuk umum bagi posisi mereka sebagai wakil. Pertama, terdapat pola yang tetap, yaitu semakin ke atas seseorang melihat hierarki pengambilan keputusan, semakin berkurang jumlah wakil perempuannya. Kedua, pembagian pekerjaan secara fungsional antara wakil-wakil perempuan dan wakil-wakil laki-laki ada dalam banyak sistem.

Al Qur'an memberikan pedoman, tidak memperbolehkan kepemimpinan publik, seperti : presiden, gubernur, bupati atau sejenisnya dipegang oleh kaum wanita berdasarkan berbagai dalil yang disebutkan didalam al Qur'an dan sunnah diantaranya : 


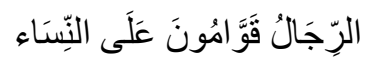

Artinya : "Kaum laki-laki itu adalah pemimpin bagi kaum wanita." (Al-qur'an, An Nisaa,4:34).

Makna yang terkandung dalam ayat tersebut adalah kaum pria lah yang berkewajiban memberikan nafkah kepada kaum wanita. Bermakna juga,'termasuk didalamnya adalah para hakim, amir (pemimpin) dan orang yang berperang dan didalam perkara itu semua tidak diperbolehkan wanita."

Pada kenyataannya masih ada pemimpin perempuan yang dalam kepemimpinannya dinilai efektif. Terlepas dari persoalan gender yang masih mengekang pikiran masayarakat terhadap kepemimpinan wanita kita harus menyadari bahwa pemimpin-pemimpin wanita tersebut memiliki kemampuan dalam memimpin. Permasalahan yang sangat sering di hadapi, bagaimanakah menilai efektivitas kepemimpinan seorang pemimpin publik.

Kanter (1977:233) mengemukakan beberapa faktor yang berpengaruh pada kepemimpinan wanita, yaitu : The Mother, dimana perempuan pemimpin dianggap sebagai ibu yang mengasuh anak-anak nya sehingga karyawan menjadi lebih simpatik karena mendengarkan dan menyelesaikan masalah dengan baik. The Pet, Perempuan pemimpin adalah favorit dan menjadi maskot karyawannya sehingga dianggap mampu menghibur dan bersenda gurau dengan karyawan. The sex object, perempuan pemimpin memotivasi kinerja karyawan untuk bekerja dengan lebih aktif, namun bukan berdasar pada perintah yang diberikan melainkan pada dorongan yang berasal dari dalam diri. The Iron Maiden, perempuan pemimpin yang perkasa, menginginkan posisi yang setara dengan siapapun dan menunjukkan kompetensi dalam organisasi sehingga bekerja secara keras dan agresif.

Bass (dalam Gibson, Ivancevich dan Donelly, 1996:13) menggambarkan kepemimpinan efektif dengan asosiasi beberapa sifat yang terdiri dari motivasi (Pertimbangan, Mampu Memutuskan, Pengetahuan, kelancaran berbicara), kepribadian (Penyesuaian diri, kesiagaan, kreativitas, integritas pribadi, percaya diri, keseimbangan emosional dan kemandirian control) dan kemampuan/kompetensi (Mendapatkan dukungan kerjasama, mampu bekerja sama, popular dan berpengaruh, sosiabilitas, parisipasi sosial, taktis dan diplomatis).

Kepala daerah dari kalangan wanita di Indonesia memang hal yang "biasa." Walikota wanita pertama Indonesia telah ada sejak 1947, yaitu Agustine Magdalena Waworuntu sebagai walikota Manado sejak akhir 1949 (dilantik pada Maret 1950). Ada juga Salawati Daud (Charlotte Salawati), walikota Makassar yang jarang diketahui banyak orang. Beliau dilantik hampir bersamaan dengan Agustine Magdalena Waworontu di provinsi Sulawesi Utara. Kemudian selanjutnya muncul pemimpin-pemimpin wanita baru dengan prestasi yang sangat patut diapresiasi. Salah satu pemimpin daerah yang terkenal dengan prestasinya dalam membangun daerah adalah walikota Surabaya, Tri Rismaharini. Ibu Risma merupakan walikota terbaik di Indonesia maupun dunia. penghargaan sebagai walikota terbaik di dapatkan Risma karena ia dapat membangun Kota Surabaya menjadi kota yang lebih rapih, dan juga saat ini menjadi kota yang cukup ramah lingkungan. Saat ini Kota Surabaya dibawah kepemimpinan Risma menjadi salah satu kota terbersih di Indonesia. Kota Surabaya juga menjadi kota yang cukup rapih di tangan Risma.

Di Provinsi Nusa Tenggara Barat, ada salah satu daerah yang dipimpin oleh pemimpin wanita, yaitu kabupaten Bima yang dikenal dengan stigma "Zona Merah" yang merupakan daerah rawan konflik. Indah Damayanti Putri atau yang akrab disapa Dae dinda menjadi wanita pertama di Bima yang menjabat sebagai Bupati. Konflik sosial yang menjadi permasalahan pelik di Kabupaten Bima merupakan tantangan tersendiri bagi seorang pemimpin dalam mencari solusinya. Konflik sering terjadi akibat dipicu oleh beberapa hal yang sebenarnya bisa diselesaikan dengan kekeluargaan namun sering kali permasalahan sepele bisa menyebabkan konflik yang harus diselesaikan dengan kekerasan. Kasus yang terjadi baru-baru ini adalah bentrok antar warga Desa Laju, Kecamatan Langgudu, dengan warga Desa Tolo Uwi, Kecamatan Monta, Kabupaten Bima, Nusa Tenggara Barat, terjadi pada Selasa, 9 Mei 2017. Akibatnya, seorang warga Laju meninggal dunia akibat perang tersebut. Selain itu, konflik berkelanjutan antar dua desa yakni Dadibou dan Risa masih belum menemukan titik terang, kedua 
desa tersebut beberapa kali saling serang meskipun sudah ada upaya mediasi dari pemerintah.

Mengatasi konflik sosial merupakan salah satu peran pemimpin yang menunjukan efektivitas kepemimpinannya, karenanya sangat menarik untuk menggambarkan bagaiman efektivitas kepemimpinan wanita dalam mengatasi konflik sosial yang pada penelitian ini mengkaji kepemimpinan Bupati Kabupaten Bima.

\section{Tinjauan Pustaka}

\section{a. Pengertian Efektivitas}

Efektivitas merupakan unsur pokok untuk mencapai tujuan atau sasaran yang telah ditentukan di dalam setiap organisasi, kegiatan ataupun program. Disebut efektif apabila tercapai tujuan ataupun sasaran seperti yang telah ditentukan. Menurut H. Emerson (dalam Handayaningrat, S 1994:16) yang menyatakan bahwa Efektivitas merupakan unsur pokok untuk mencapai tujuan atau sasaran yang telah ditentukan didalam setiap organisasi, kegiatan ataupun program. Sementara itu Commision, A (dalam Mahsun 2006:180) menyatakan bahwa efektivitas adalah menyediakan jasa-jasa yang benar sehingga memungkinkan pihak yang berwenang untuk mengimplementasikan kebijakan dan tujuannya. Kemudian Mahsun (2006:182) menjelaskan bahwa efektivitas (hasil guna) merupakan hubungan antara keluaran dengan tujuan atau sasaran yang harus dicapai. Pengertian efektivitas ini pada dasarnya berhubungan dengan pencapaian tujuan atau target kebijakan.

Kebijakan operasional dikatakan efektif apabila proses kegiatan tersebut mencapai tujuan dan sasaran akhir kebijakan (spending wisely). Dunn (2000:429) menerangkan bahwa efektivitas (effectiveness) berkenaan dengan apakah suatu alternatif mencapai hasil (akibat) yang diharapkan, atau mencapai tujuan dari diadakannya tindakan. Efektivitas,yang secara dekat berhubungan dengan rasionalitas telaris, selalu diukur dari unit produksi atau layanan atau nilai moneternya. Selanjutnya, Dunn (2000:601) menambahkan bahwa efektivitas merupakan kreteria evaluasi yang mempertanyakan apakah hasil yang diinginkan telah tercapai.

\section{b. Pengertian Kepemimpinan}

Kepemimpinan (Leadership) adalah kemampuan seseorang (yaitu pemimpin atau leader) untuk mempengaruhi orang lain (yaitu yang dipimpin atau pengikut-pengikutnya). Sehingga orang lain tersebut bertingkah-laku sebagaimana kehendaki oleh pemimpin tersebut. Kadangkala dibedakan antara kepemimpinan sebagai kedudukan dan kepemimpinan sebagai suatu proses sosial (Koentjaraningrat, 1967:181). Sebagai kedudukan, kepemimpinan merupakan suatu kompleks dari hak-hak dan kewajibankewajiban yang dapat dimiliki oleh seseorang atau suatu badan. Sebagai salah satu proses sosial, kepemimpinan meliputi segala tindakan yang dilakukan seseorang atau sesuatu badan yang menyeb abkan gerak dari warga masyarakat (Soekanto, 1990: 318-319).

\section{c. Efektivitas Kepemimpinan}

Efektivitas kepemimpinan dapat dipandang sebagai ukuran sampai sejauh mana seorang pemimpin dapat melaksanakan seluruh pekerjaannya dalam memimpin organisasi mencapai sasaran atau tujuannya. Efektivitas merupakan suatu kegiatan atau tugas pokok yang dilaksanakan untuk mencapai tujuan organisasi dengan cara memaksimalkan tujuan agar sasaran yang dicapai dapat dinilai tepat dan positif. suatu kepemimpinan dapat dikatakan efektif apabila seorang pemimpin dapat melaksanakan fungsi-fungsinya secara baik dalam rangka mencapai sasaran atau tujuan organisasinya.

Bass (dalam Gibson, Ivancevich dan Donelly, 1996:13) menggambarkan kepemimpinan efektif dengan asosiasi beberapa sifat yang terdiri dari motivasi (Pertimbangan, Mampu Memutuskan, Pengetahuan, kelancaran berbicara) , kepribadian (Penyesuaian diri, kesiagaan, kreativitas, integritas pribadi, percaya diri, keseimbangan emosional dan kemandirian control) dan kemampuan/kompetensi (Mendapatkan dukungan kerjasama, mampu bekerja sama, popular dan berpengaruh, sosiabilitas, partisipasi sosial, taktis dan diplomatis).

\section{d. Faktor-Faktor yang Memengaruhi Efektivitas Kepemimpinan}

Sopiah (2008 : 116) mengemukakan faktorfaktor yang mempengaruhi efektivitas kepemimpinan mencakup kepribadian, pengalaman 
masa lampau dan harapan dari pimpinan tersebut, harapan dan perilaku atasan, karakteristik, harapan dan perilaku bawahan, persyaratan tugas, kultur, kebijaksanaan organisasi dan harapan serta perilaku rekan. Pada gilirannya faktor-faktor ini juga mempengaruhi pemimpin. Proses pengaruh tersebut bersifat timbal balik antara pemimpin dan anggota kelompok, saling mempengaruhi hingga mempengaruhi efektivitas kelompok secara keseluruhan. Nilai, latar belakang dan pengalaman pemimpin mempengaruhi pilihan gaya kepemimpinan seseorang. Sering pemimpin yang telah berhasil melaksanakan supervisi kecil, misalnya atau yang menghargai kebutuhan pemenuhan diri bawahan mungkin memilih gaya kepemimpinan yang berorientasi pada pegawai / karyawan. Seorang pemimpin yang tidak mempercayai bawahan atau benar-benar ingin mengelola semua aktivitas kerja secara langsung mungkin memilih gaya kepemimpinan yang otoriter.

Pada umumnya pemimpin mengembangkan gaya kepemimpinan yang paling menyenangkan bagi dirinya. Kenyataan bahwa kepribadian atau pengalaman masa lampau seorang pemimpin membantu membentuk gaya kepemimpinannya tidaklah berarti bahwa gaya tersebut tidak dapat diubah. Pemimpin belajar bahwa gaya tertentu memberikan hasil yang lebih baik bagi mereka daripada gaya lainnya. Jikalau suatu gaya ternyata tidak cocok, mereka dapat mengubahnya. Akan tetapi perlu diingat bahwa pemimpin yang mencoba memilih gaya yang sangat tidak sesuai dengan kepribadian dasarnya maka mustahil untuk menggunakan gaya tersebut secara efektif. Harapan seorang pemimpin juga merupakan faktor yang berpengaruh. Telah diperlihatkan karena berbagai alasan, situasi cenderung berkembang ke arah yang kita inginkan. Harapan pemimpin mengenai gaya yang diperlukan agar bawahannya bekerja secara efektif mempengaruhi pilihan gaya kepemimpinannya (Sopiah, 2008 : 118).

\section{Metode Penelitian}

Tujuan penelitian ini adalah untuk mengetahui Efektivitas kepemimpinan Bupati Bima dalam mengatasi konflik sosial yang terjadi di Kabupaten Bima, adapun metode penelitian yang digunakan dalam penelitian ini adalah pendekatan paradigma kualitatif, dengan jenis penelitian deskriptif, dengan tekhnik pengumpulan data melalui wawancara dan dokumentasi.

\section{Hasil dan pembahasan}

a) Efektivitas kepemimpinan bupati bima dalam mengatasi konflik

Berdasarkan hasil penelitian, penulis mencoba menganalisis efektivitas kepemimpinan Bupati Bima dalam mengatasi konflik berdasarkan persepsi dari beberapa narasumber yang sudah peneliti wawancarai dengan mengajukan 21 pertanyaaan secara terstruktur. Efektivitas kepemimpinan dalam penelitian ini diukur berdasarkan motivasi (Pertimbangan, Mampu Memutuskan, Pengetahuan, kelancaran berbicara), kepribadian (Penyesuaian diri, kesiagaan, kreativitas, integritas pribadi, percaya diri, keseimbangan emosional dan kemandirian control) dan kemampuan/kompetensi

(Mendapatkan dukungan kerjasama, mampu bekerja sama, popular dan berpengaruh, sosiabilitas, parisipasi sosial, taktis dan diplomatis), (Bass, dalam Gibson, Ivancevich dan Donelly, 1996:13).

a. Motivasi

Motivasi dan kepemimpinan merupakan 2 hal yang berbeda, meski memiliki tautan dalam konteks kerja dan interaksi antar manusia organisasional. Tanpa kepemimpinan organisasi hanya merupakan kelompok manusia yang kacau, tidak teratur dan tidak dapat melahirkan perilaku bertujuan. Kepemimpinan adalah faktor manusiawi yang mengikat suatu kelompok bersama dan memberinya motivasi menuju tujuan tertentu, baik dalam jangka pendek maupun jangka panjang, berarti kepemimpinan dengan motivasi memiliki ikatan yang kuat.

Motivasi dalam mencapai tujuan, seorang pemimpin harus mampu mempertimbangkan langkah apa saja yang harus dilakukan agar dapat memberikan pengaruh yang positif terhadap sesuatu yang menjadi target pencapaian. Seperti halnya dalam penanganan konflik, seorang pemimpin harus memiliki motivasi dalam meredam konflik.

Seorang pemimpin harus bisa mempertimbangkan serta mengambil keputusan yang tepat dalam penanganan 
konflik. Seperti yang dilakukan oleh Bupati Bima pada saat penanganan konflik. Bupati melakukan koordinasi dengan berbagai lembaga terkait yakni pemerintah desa dan kecamatan untuk mengupayakan kata damai melalui islah. Dengan difasilitasinya dan dilakukannya islah tersebut masyarakat yang bertikai akan lebih cepat sepakat untuk damai dikarenakan pemuka-pemuka masyarakat yang bertikai dipertemukan secara langsung agar konflik yang terjadi menemui titik terang.

Adanya visi dan misi yang dimiliki oleh seorang Bupati menjadi motivasi dalam kepemimpinan sehingga tujuan dan harapan yang dicita-citakan bersama akan tercapai, lebih jelas dan mengenai sasaran. Dalam hal ini terlihat bahwa bupati memiliki komitmen serta motivasi yang kuat dalam menciptakan rasa aman dan damai di Kabupaten Bima.

Sebagai pemimpin wanita yang memimpin di daerah yang rawan konflik, bupati Bima memiliki motivasi kepemimpinan yang sangat kuat dalam penanganan konflik guna mencari solusi terbaik sehingga tercapai Misi Pemerintah Kabupaten Bima yaitu Bima RAMAH.

Dari pemaparan beberapa narasumber, terlihat bahwa solusi terbaik dan kata perdamaian menjadi motivasi kepemimpinan Bupati Bima dalam menangani konflik. Dalam hal ini, untuk mencapai tujuan perdamaian, Bupati Bima berkoordinasi dengan pemerintah kecamatan memfasilitasi upaya Islah untuk kedua desa yang terlibat konflik, dan ini merupakan upaya Bupati dalam penanganan konflik.

Bupati Bima juga dinilai memiliki komitmen yang sangat tinggi dalam upaya meredam konflik yang sering terjadi dikabupaten Bima, hal tersebut terbukti dengan diusungnya visi Bima RAMAH dalam kepemimpinan bupati Bima yang sekarang. Visi pemerintah Kabupaten Bima saat ini adalah Terwujudnya Pembangunan Kabupaten Bima yang RAMAH " Religius, Aman, Makmur, Amanah dan Handal". Hal inilah yang menjadi acuan bupati Bima untuk meredam konflik sehingga Bima menjadi salah satu Kabupaten yang keamanannya terjaga.

Maka dari itu, Selaras dengan apa yang telah diusung oleh bupati Bima saat ini, apa yang menjadi tujuan dan acuan bupati bima dalam kepemimpinannya sesuai dengan pendapat dari salah satu ahli yang mengatakan "Motivasi adalah suatu proses untuk menggiatkan motif-motif menjadi perbuatan / tingkah laku untuk memenuhi kebutuhan dan mencapai tujuan / keadaan dan kesiapan dalam diri individu yang mendorong tingkah lakunya untuk berbuat sesuatu dalam mencapai tujuan.” (Burhanudin, 1994:157).

\section{b. Sifat/Kepribadian}

Menjadi seorang pemimpin yang efektif secara alami hanya memerlukan seseorang untuk berhenti berusaha menjadi orang lain atau beberapa kombinasi dari orang lain. Tentu saja pemimpin yang efektif mulai dengan menjadi diri sendiri. Maka dari itu, salah satu dari teori kepemimpinan adalah Teori kepemimpinan sifat.

Teori kepemimpinan sifat adalah suatu pandangan atau pendapat yang mengatakan bahwa efektivitas seorang pemimpin banyak ditentukan oleh sifat- sifat atau karakter yang dimiliki oleh pemimpin tersebut. Hasil penelitian menunjukkan bahwa ciri-ciri pemimpin yang efektif adalah "Emotional Intelligence (El)" yang dimana empati merupakan salah satu unsur penting yang ada didalamnya.

Bupati bima sekarang dianggap memiliki kepribadian/sifat kepemimpinan yang cepat tanggap dilihat dari reaksi serta penyesuaian diri bupati dalam menangani konflik sosial yang terjadi. Pada saat terjadi konflik bupati tidak segan untuk melakukan pendekatan dengan berbagai elemen masyarakat. Pendekatan tersebut dilakukan untuk mencari akar permasalahan yang terjadi sehingga penanganan konflik bisa dilakukan dengan cepat dan tepat.

Bupati bima melakukan cara-cara yang dapat meminimalisir konflik yang terjadi dimasyarakat berupa pendekatan secara langsung baik pendekataan kelembagaan maupun turun secara langsung kemasyarakat.

Seorang pemimpin yang memiliki kepribadian mudah memahami emosi dirinya dan mampu membaca emosi orang lain, dapat lebih efektif dalam pekerjaannya. Maka dari itu pemimpin yang efektif harus memiliki sifat emosional yang seimbang. Dimensi ini menunjukkan kemampuan seseorang menghadapi tekanan serta cenderung bersikap 
tenang, penuh percaya diri, dan nyaman. Maka dari itu, menjadi seorang pemimpin tidaklah mudah, apalagi bagi seorang perempuan pasti harus bisa menciptakan suasana yang harmonis dengan lingkungan masyarakat yang dipimpin dan harus mempunyai langkah-langkah dalam upaya mewujudkan kesejahteraan masyarakat serta harus sigap dalam bertindak terutama pada saat terjadi konflik didaerah yang dipimpinnya.

Kesigapan seorang pemimpin sudah tercermin dalam kepemimpinan bupati Bima, terlihat dari upaya bupati Bima dengan sigap menurunkan pasukan keamanan untuk penanganan awal pada saat terjadi konflik, dan jika memungkinkan Bupati Bima turun langsung dalam penanganan konflik. Selain itu juga, kesabaran dalam menghadapi tekanan serta cenderung bersikap tenang juga tercermin dari upaya bupati untuk tetap mengupayakan musyawarah mufakat.

Pemimipin yang memiliki integritas adalah pemimpin yang sukses dalam jangka panjang. Integritas adalah kesesuaian antara yang dikatakan dengan yang dilakukan oleh seseorang. Bupati Bima adalah seorang pemimpin yang memiliki interitas yang tinggi dalam menciptakan kedamaian di kabupaten Bima yang merupakan daerah zona merah rawan konflik.

Bupati Bima memiliki sifat empati yang tinggi sehingga pada saat terjadi konflik dengan cepat mampu menyesuaikan diri dengan melakukan pendekatan-pendekatan kelembagaan dengan berkoordinasi dengan instansi terkait seperti TNI/POLRI, Kesbangpol, sampai jajaran kebawah termasuk kecamatan sampai dengan desa serta pendekatan kemasyarakat secara langsung hal tersebut terlihat dari pendekatan serta kesigapan yang telah dilakukan bupati Bima pada saat terjadi konflik. Sehingga hal tersebut mencerminkan integritas pribadi seorang kepala daerah sangat baik. Disamping itu juga, bupati Bima selaku pemimpin yang memimpin di daerah yang rawan konflik, dimana sewaktu-waktu konflik bisa saja terjadi, Bupati Bima dengan sigap melakukan pendekatan serta penyesuaian diri terhadap situasi tersebut dengan membaca reaksi dari masyarakat yang terlibat konflik serta mendengarkan apa yang menjadi permasalahan yang menyebabkan konflik itu terjadi. Ini menunjukan bahwa bupati memiliki keseimbangan emosional yang cukup baik karena bupati tetap mengedepankan musyawarah mufakat untuk memberikan dan mewujudkan rasa aman, terutama dalam penanganan konflik.

Uraian diatas menunjukan bahwa bupati Bima memiliki sifat kecerdasan emosional (Intelegency Emotional) atau yang di singkat dengan EI. Hal tersebut menunjukan adanya sinkronisasi antara kepribadian bupati dengan teori yang dikemukan oleh Robbin dan Judge(2007:357-358), komponen utama dari El adalah empati (empathy). Pemimpin yang memiliki empati yang tinggi, dapat merasakan kebutuhan orang lain, mendengarkan apa yang dikatakan dan apa yang tidak dikatakan oleh pengikut, dan dapat membaca reaksi orang lain. Bagian dari empati, terutama perhatian pemimpin kepada orang-orang yang bekerja dengannya, adalah hal yang membuat orang tetap mau membantu pemimpin tersebut, walaupun keadaan menjadi sulit/buruk.

c. Komptensi/Kemampuan

Kegiatan memimpin merupakan usaha yang dilakukan oleh seseorang dengan segenap kemampuan yang dimilikinya untuk mempengaruhi, mendorong, mengarahkan dan menggerakan orang-orang yang dipimpin supaya mereka mau bekerja dengan penuh semangat dan kepercayaan dalam mencapai tujuannya. Kemampuan seorang pemimpin dalam segala hal inilah yang disebut dengan kompetensi dalam memimpin.

Pemimpin harus menguasai cara-cara kepemimpinan, memiliki kompetensi dalam memimpin supaya dapat bertindak sebagai seorang pemimpin yang baik. Untuk hal itu antara lain dia harus menguasai bagaimana caranya : menyusun rencana bersama, mengajak anggota berprestasi, memberi bantuan kepada anggota kelompok, memupuk moral kelompok, bersama-sama membuat keputusan, menghindarkan "working on the 
group and working for the group" dan mengembangkan "working within the group", membagi dan menyerahkan tanggung jawab, dan sebagainya. Untuk memperoleh kompetensi di atas, diperlukan pengalaman yang mempuni dikarenakan pemimpin harus benar-benar banyak bergaul, bekerjasama, dan berkomunikasi dengan orang yang dipimpinya terutama pada saat terjadi konflik.

Dalam penangan konflik, pemimpin harus bisa menjalin kerja sama dengan berbagai elemen dalam upaya meredam koflik. Kemampuan pemimpin menjalin kerja sama akan mendapatkan dukungan penuh dari bawahan sehingga tercipta kerja sama yang solid antara atasan dan bawahan.

Terlihat langkah awal yang dilakukan oleh bupati dalam penanganan konflik. Bupati berkoordinasi dengan lembagalembaga terkait pada saat terjadi konflik. Hal ini dilakukan untuk mencegah terjadinya konflik yang lebih besar dan konflik tidak berkenlanjutan.

Selain menjalin kerja sama dengan lembaga-lembaga terkait, seorang pemimpin daerah juga harus bisa membangun komunikasi yang baik dengan masyarakat. Pemimpin yang efektif adalah pemimpin yang terkenal dengan kepedulian sosial yang tinggi sehingga berpengaruh terhadap interaksi dalam kepemimpinan. Pemimpin daerah dengan partisipasi sosial yang tinggi mudah mendapatkan simpati dari masyarakat yang dipimpinnya. Itu juga yang sering dilakukan oleh bupati Bima pada saat terjadi konflik.

Kemampuan pendekatan yang dilakukan oleh bupati bima masih terbilang tidak merata disetiap wilayah yang terlibat konflik. Hal ini dibuktikan dengan tidak sinkronnya pernyataan yang diberikan oleh wakil bupati dan anggota DPR dengan masyarakat yang terlibat konflik. Pendakatan yang dilakukan oleh bupati Bima memang sudah dilakukan dari segi kelembagaan namun pendekatan kepada masyarakat secara langsung masih tidak merata.

Pemimpin yang efektif merupakam pemimpin yang mampu bersosialisasi dengan masyarakatnya dengan baik, pemimpin yang memiliki kepedulian yang tinggi kepada masyarakat tanpa memandang status dan pekerjaanya. Sifat sosial bupati tercermin dari partisipasi bupati dalam kehidupan masyarakat secara lengsung, terutama pada saat terjadi konflik.

Dari uraian diatas, mencerminkan bagaimana kemampuan bupati Bima dalam membangun hubungan sosial dengan masyarakat yang dipimpinnya. Dengan tindakan tanpa memandang status dan pangkat dalam berinteraksi, menjadikan bupati Bima menjadi sosok yang memiliki jiwa sosiabilitas yang tinggi.

Berdasarkan uraian pernyataan yang ungkapkan oleh berbagai narasumber, bupati Bima memiliki kemampuan berkoordinasi dalam menjalin kerjasama guna menciptakan rasa aman dan nyaman serta ketertiban umun. Bupati bersinergi dengan berbagai elemen dengan menciptakan interaksi sosial yang komunikatif melalui musyawarah mufakat dalam penanganan konflik.

Dalam berbagai kesempatan, bupati selalu mengemukakan, kantibmas merupakan salah satu yang harus diperhatikan oleh Kepala daerah, Kepolisian dan seluruh warga masyarakat dalam rangka menciptakan rasa keamanan dan kenyamanan warga dalam melaksanakan rutinitas. Maka dari itu, jika terjaadi konflik disuatu desa, bupati dengan sigap melakukan koordinasi dengan berbagai elemen seperti kepolisian dan kepala desa dan tokoh masyarakat yang ada didesa yang terlibat konflik untuk mencegah terjadinya konflik yang lebih parah dan kodratnya sebagai perempuan yang lemah lembut, menjadi pendukung dalam melakukan pendekatan sosial pada saat terjadi konflik. Bupati wanita dengan karisma kepemimpinannya yang populer memiliki pengaruh positif dalam meredam emosi masyarakat yang dipimpinnya.

Bersosialisasi, berinteraksi langsung dengan masyarakat dan melakukan pendekatan-pendekatan dengan berbagai elemen maka akan mudah terciptanya suasana yang harmonis di lingkungan masyarakat antara bupati dengan masyarakat. Meskipun dalam hal ini, pendekatan yang dilakukan bupati dengan masyarakat belum merata.

Menurut Wibowo (2012:324) menjelaskan bahwa kompetensi adalah sebagai berikut : "Suatu kemampuan untuk melaksanakan suatu pekerjaan yang dilandasi atas keterampilan dan pengetahuan serta 
didukung oleh sikap yang dituntut oleh Saran pekerjaam tersebut".

Dikaitkan dengan kemampuan bupati dalam menjalankan tugasnya sebagai kepala daerah dalam meredam konflik, teori ini sangat relevan dengan hal tersebut. Karena dalam hal ini, bupati sebagai kepala daerah mampu menjalin kerja sama dengan berbagai lembaga serta kepribadian sosiabilitas yang tinggi yang dimiliki bupati sesuai dengan tugasnya sebagai kepala daerah yang menjamin keamanan serta kesejahteraan masyarakat yang dipimpinnya.

\section{SIMPULAN}

Kepemimpinan Bupati Kabupaten Bima $\mathrm{Hj}$. Indah Damayanti Putri dikatakan efektif baik dalam bidang sosial maupun mutu secara universal. Hal ini dapat di deskripsikan sebagai berikut :

1. Dinilai dari motivasi kepemimpinan, tercapainya visi misi Bupati Bima sudah terlihat dan terbukti dengan menurunnya angka konflik, kebersamaan masyarakat yang terlihat melalui aktivitas-aktivitas budaya, keagamaan, sosial serta nilai patriotisme negara.

2. Dinilai dari Sifat/kepribadian seorang pemimpin, tercapainya visi misi juga dipengaruhi oleh kepribadian yang karismatik dari bupati Bima yang disukai oleh masyarakat atau menumbuhkan sikap simpati dan dijadikan teladan bagi masyarakat Kabupaten Bima.

3. Dinilai dari kompetensi/kemampuan dari seorang pemimpin, terwujudnya koordinasi dalam bentuk kerja sama yang baik antara berbagai lembaga (SKPD) di Kabupaten Bima terutama dalam penanganan konflik.

Dengan demikian upaya mengurangi atau mengatasi berbagai konfli di Kabupaten Bima dilakukan secara berkesinambungan dan terusmenerus agar konflik tidak tergenerasikan, sehingga mewujudkan Bima yang RAMAH bukan mimpi belaka.

Saran yang disampaikan oleh penulis adalah:

1. Melakukan pemberdayaan kepada pemudapemuda yang masih menganggur seperti, pelatihan perbengkelan, sablon, dll.

2. Mewajibkan pelajaran Imtaq dan budipekerti, di setiap sekolah dengan memberikan binaan moral dan akhlak kepada pelajar guna membina moral dan memupuk rasa saling menghargai dan menghormati dan saling menyayangi.

3. Memperbaiki akses menuju tempat-tempat wisata sehingga wisatawan tertarik untuk berkunjung dan masyarakat setempat bisa membuka usaha dan menciptakan lapangan pekerjaan baru.

4. Melakukan sosialisasi keamanan tentang kamtibmas adalah tanggung jawab bersama. Peran serta masyarakat dalam menjaga rasa kenyamanan dilingkungan sangat diharapkan, karena itu yang dibutuhkan sekarang adalah bagaimana antara Masyarakat dan Polri terjalin suatu hubungan yang sinergis dalam mengupayakan terwujudnya kondisi kamtibmas yang stabil, sehingga dapat mendukung pembangunan yang akan dilaksanakan menuju masyarakat yang adil dan makmur, spiritual dan material.

\section{Daftar Pustaka}

[1] Abdullah, M., Kusuma, A.R., dan Irawan, B. (2014). Efektivitas gaya kepemimpinan Lurah dalam pelayanan publik pada kantor kelurahan Rawa Makmur Kecamatan Palaran Kota Samarinda. Diakses 29 Desember 2017,

[2] Al-qur'an dan Terjemahnya:Al-jumanatul 'Ali, Departemen Agama RI, CV Penerbit J-Art, Bandung, 2004.

[3] Arikunto, S., Prosedur Penelitian: Suatu Pendekatan Praktek (Edisi Revisi Kelima), Rineka Cipta, Jakarta, 2002.

[4] Burhanuddin, Analisis Administrasi Manajemen Dan Kepemimpinan, Bumi Aksara, Jakarta, 1994.

[5] Dahrendorf, Sosiologi Ilmu Pengetahuan Berparadigma, Ganada Rajawali Press, Jakarta, 1998. 
[6] Dunn, W.N., Pengantar Analisis Kebijakan Publik, Gadjah Mada University Press, Yogyakarta, 2009.

[7] Gibson, J., Ivancevich, J., dan Donnelly, J.H., Organisasi: Perilaku, Struktur, Proses (Edisi 8 jilid 2). Alih bahasa : Nunuk Adiarni, Binarupa Aksara, Jakarta, 1996.

[8] Gulo, W., Metodologi Penelitian, PT Gramedia Widiasarana Indonesia, Jakarta, 2003.

[9] Handayaningrat, S., Pengantar Studi Administrasi dan Manajemen, CV Haji masagung, Jakarta, 1994.

[10]Kanter, R.M., Men and Women of the Corporation, Harper Collins Publishers, New york, 1977.

[11] Koentjaraningrat, Beberapa Pokok Antropologi Sosial, Dian Rakyat, Djakarta, 1967.

[12] Kurniawan, A., Transformasi Pelayanan Publik, Pembaharuan, Yogyakarta, 2005.

[13]Lawang, R., Buku Materi Pokok Pengantar Sosiologi, Universitas Terbuka, Jakarta, 1994.

[14] Mahsun, M., Pengukuran Kinerja Sektor Publik, BPFE, Yogyakarta, 2006.

[15] Miles, M. B., Analisis Data Kualitatif Buku Sumber Tentang Metode - Metode Baru, Terjemahan Tjetjep Rohendi Rohidi, UI pres: Jakarta, 1992.

[16] Moleong, L. J., Metodologi Penelitian Kualitatif, Remaja rosdakarya, Bandung, 2013.

[17] Muflihin, M. H., Kepemimpinan Pendidikan : Tinjauan TerhadapTeori Sifat dan Tingkah Laku, INSANIA, Purwokerto, 2008.

[18] Narwoko, J.D., dan Suyanto, B, Sosiologi Teks Pengantar dan Terapan, Kencana Prenada Media Group, Jakarta, 2005.

[19]Pasolong, H., Teori Administrasi Publik, Alfabeta, Bandung, 2007.

[20] Republik Indonesia, UU No. 7 Tahun 2012 tentang Penanganan Konflik sosial, Lembaran Negara RI Tahun 2012, No. 116, Sekretariat Negara, Jakarta, 2012.

[21] Robbin, S.P., dan Judge, Perilaku organisasi, Salemba, Jakarta, 2007.

[22] Santoso, T., Kekerasan Agama Tanpa Agama, Pustaka Utan Kayu, Surabaya, 2001.

[23] Soekanto, S, Sosiologi Suatu Pengantar, PT. Raja Grafindo Persada, Jakarta, 1990.

[24] Sopiah, Perilaku Organisasi, ANDI OFFSET, Yogyakarta, 2008.

[25] Steers, R.M., Efektivitas Organisasi alih bahasa : Magdalena Jamin, Erlangga, Jakarta, 1985.

[26] Wahjosumidjo, Kepemimpinan Kepala Sekolah, PT. Raja Grasindo Persada, Jakarta, 2013.
[27]Dewi, I. (2009). Model kepemimpinan Efektif. Diakses 29 Desember 2017, https://ojs.unud.ac.id/index.php/piramida/articl elview/2987/2145

[28]Lutfiana. N. (2003). "Kepemimpinan Kepala Desa Perempuan Di Desa Karas Kepoh Kecamatan Pancur Kabupaten Rembang". Skripsi Sarjana jurusan politik dan kearganegaraan. Fakultas Ilmu Sosial: Universitas Negeri Semarang. ( Dipublikasikan) http://lib.unnes.ac.id/19980/1/3301409059.pdf

[29] Rahma, S., Suhandana, G.A., dan Suarni, N,K. (2013). Kontribusi efektivitas kepemimpinan, budaya organisasi dan etos kerja terhadap kepuasan kerja pegawai balai diklat keagamaan Denpasar. Di akses pada 29 Desember 2017, pasca.undiksha.ac.id/ejournal/index.php/jurnal_ap/article/viewFile/63 $7 / 422$

[30] Sukardi. (2016). Penanganan Konflik Sosial Dengan Pendekatan Keadilan Restoratif. Diakses pada 3 Januari 2018, jhp.ui.ac.id/index.php/home/article/download/4 9/pdf 